\title{
The burden of stroke and transient ischemic attack in Pakistan: a community-based prevalence study
} Ayeesha Kamran Kamal ${ }^{* \dagger 1}$, Ahmed Itrat ${ }^{\dagger 1}$, Muhammed Murtaza ${ }^{2}$, Maria Khan ${ }^{1}$, Asif Rasheed ${ }^{3}$, Amin Ali², Amna Akber ${ }^{4}$, Zainab Akber ${ }^{4}$, Naved Iqbal ${ }^{4}$, Sana Shoukat ${ }^{2}$, Farzin Majeed ${ }^{1}$ and Danish Saleheen ${ }^{5}$

Address: ${ }^{1}$ Stroke Service, Section of Neurology, Department of Medicine, Aga Khan University Hospital, Karachi, Pakistan, ${ }^{2}$ Medical College, Aga Khan University Hospital, Karachi, Pakistan, ${ }^{3}$ Department of Biological and Biomedical Sciences, Aga Khan University Hospital, Karachi, Pakistan, ${ }^{4}$ Dow University of Health Sciences, Karachi, Pakistan and ${ }^{5}$ Department of Public Health and Primary Care, University of Cambridge, UK

Email: Ayeesha Kamran Kamal* - ayeesha.kamal@aku.edu; Ahmed Itrat - ahmeditrat@gmail.com; Muhammed Murtaza - murtaza@consulnet.net; Maria Khan - maria.khan@aku.edu; Asif Rasheed - dr_asifrasheed@yahoo.com; Amin Ali - aminali@gmail.com; Amna Akber - amnaakber@gmail.com; Zainab Akber - zainabakber@gmail.com;

Naved Iqbal - navaid_iqbal@yahoo.com; Sana Shoukat - sana_shoukat@hotmail.com; Farzin Majeed - farzin.majeed@aku.edu; Danish Saleheen - DS436@medschl.cam.ac.uk

* Corresponding author †Equal contributors

Published: I December 2009

BMC Neurology 2009, 9:58 doi:10.1186/147|-2377-9-58
Received: 14 July 2009

Accepted: I December 2009

This article is available from: http://www.biomedcentral.com/147/-2377/9/58

(C) 2009 Kamal et al; licensee BioMed Central Ltd.

This is an Open Access article distributed under the terms of the Creative Commons Attribution License (http://creativecommons.org/licenses/by/2.0), which permits unrestricted use, distribution, and reproduction in any medium, provided the original work is properly cited.

\begin{abstract}
Background: The burden of cerebrovascular disease in developing countries is rising sharply. The prevalence of established risk factors of stroke is exceptionally high in Pakistan. However, there is limited data on the burden of stroke and transient ischemic attack (TIA) in South Asia. We report the first such study conducted in an urban slum of Karachi, Pakistan.

Methods: Individuals 35 years of age or older were invited for participation in this investigation through simple random sampling. A structured face-to-face interview was conducted using a pretested stroke symptom questionnaire in each participant to screen for past stroke or TIA followed by neurological examination of suspected cases. Anthropometric measurements and random blood glucose levels were recorded. Multivariable logistic regression was used to determine the association of vascular risk factors with prevalence of stroke.

Results: Five hundred and forty five individuals (49.4\% females) participated in the study with a response rate of $90.8 \%$. One hundred and four individuals $(19.1 \%)$ were observed to have a prior stroke while TIA was found in 53 individuals $(9.7 \%)$. Overall, II 19 individuals $(21.8 \%$ with $66.4 \%$ females) had stroke and/or TIA. Female gender, old age, raised random blood glucose level and use of chewable tobacco were significantly associated with the prevalence of cerebrovascular disease.

Conclusion: This is the first study demonstrating an alarmingly high life-time prevalence of cerebrovascular disease in Pakistan. Individual and public health interventions in Pakistan to increase awareness about stroke, its prevention and therapy are warranted.
\end{abstract}




\section{Background}

The risk of stroke has increased by $100 \%$ in low and middle income countries over the last decade and the developing world accounts for $85.5 \%$ of mortality due to all stroke deaths worldwide[1] Socioeconomic transition in low and middle income countries is likely to increase the burden of cerebrovascular disease[2] Patients who suffer from stroke in countries such as Pakistan are almost a decade younger than their western counterparts and thus, the disability in stroke survivors and resulting economic losses may be greater[3]

The prevalence of modifiable risk factors for stroke in the Pakistani population is alarmingly high. Hypertension affects one in three adults aged greater than 45 years and $19 \%$ of the population aged 15 years and above[4] The National Health Survey of Pakistan showed that diabetes mellitus is present in $35 \%$ of people older than 45 years[4] The overall prevalence of obesity is $28 \%$ in women and $22 \%$ in men while the prevalence of tobacco use is $33 \%$ in men and $4.7 \%$ in women[5,6] Given the wide prevalence of risk factors, the burden of stroke in Pakistan is likely to be substantial.

Transient Ischemic Attack (TIA) defines a subset of patients prone to stroke who may benefit from timely intervention. The immediate risk of stroke is about $10 \%$ in the first 90 days after a TIA with $50 \%$ of this risk in the first 48 hours[7] Data from Pakistan also supports these observations[8] Early intervention after TIA has shown an $80 \%$ relative risk reduction in the emergence of stroke in western cohorts $[9,10]$ This clinically recognizable syndrome is an important pragmatic entry point for stroke prevention in those at highest risk of "conversion" [11]

No multiethnic prevalence studies of stroke or TIA have been reported from Pakistan to date. The present study reports the life-time prevalence of stroke and TIA and their associated modifiable risk factors in a multiethnic urban population.

\section{Methods Study Population}

A randomized community-based cross-sectional survey was conducted between September 2008 and January 2009 in Bilal Colony which is an urban slum in Karachi, the largest metropolitan city of Pakistan. This community has a history of interaction with the Aga Khan University (AKU) through a community outreach center established by our collaborators in Department of Pediatrics and Child Health[12]

According to a recent census (August 2008) conducted by the same department, the population of Bilal Colony is 76,361 individuals in 10,925 households with an average monthly household income equivalent to $\$ 124 \pm \$ 93$ US dollars. In context, Gross National Income (GNI) per capita per annum in Pakistan is $\$ 980$ US dollars[13] Urdu, Punjabi, Baluchi and Pushto are the major languages spoken in this multiethnic population and more than 99\% people are Muslims. Roughly 50\% have received no education while $10 \%$ have received religious education only.

\section{Study Design}

Census data was used to generate a simple random list of households where individuals above the age of 35 years resided. Community health workers (CHWs, trained volunteers with at least 6 years of work experience in Bilal Colony) visited the selected households to invite eligible individuals for face-to-face interviews. Single individuals from each household who met the inclusion criteria were invited. An additional batch of multilingual community volunteers accompanied the team to provide ease of conversation. Invitations along with an information leaflet were provided at these home visits.

All men and women aged 35 years or above who were residents of Bilal Colony for two years or more were eligible for the study. Upon non-availability or refusal by an individual, the next household on the list was approached. Recruitment was continued for a total of 15 days until the targeted sample size was reached.

\section{Sample Size Estimation}

Using a 95\% confidence, 5\% estimated stroke prevalence reported previously and 2\% bounds of error; a required sample size of 457 participants was calculated. Six hundred households were approached during the study period. In order to establish if our sample was representative of the community at large, age and gender distribu-

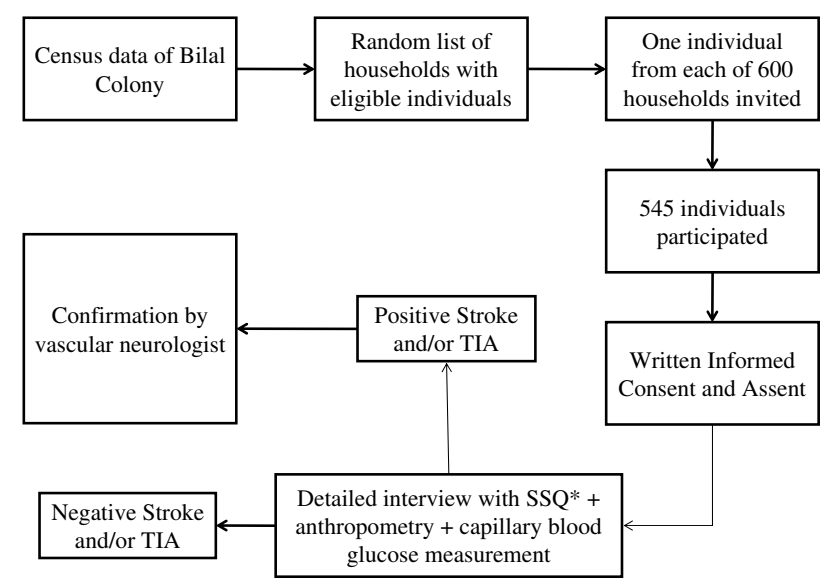

\section{Figure I}

Overview of the study design. $* S \mathrm{SQ}=$ Stroke Symptom Questionnaire. 
Table I: Socio-demographic characteristics of the study population $(n=545)$

\begin{tabular}{|c|c|c|c|}
\hline & Males $(n=276)$ & Females(n= 269) & Total $(n=545)$ \\
\hline & $\mathbf{N}(\%)$ & $n(\%)$ & $n(\%)$ \\
\hline \multicolumn{4}{|l|}{ Age (years) } \\
\hline $35-45$ & $123(44.6)$ & $164(61.0)$ & $287(52.7)$ \\
\hline $46-55$ & $52(18.8)$ & $64(23.8)$ & $116(21.3)$ \\
\hline $56-65$ & $48(17.4)$ & $29(10.8)$ & $77(14.1)$ \\
\hline $65-75$ & $33(12.0)$ & $10(3.7)$ & $43(7.9)$ \\
\hline More than 75 & $20(7.2)$ & $2(0.7)$ & $22(4.0)$ \\
\hline \multicolumn{4}{|l|}{ Ethnicity } \\
\hline Pathan & $91(33.0)$ & $58(21.6)$ & $149(27.3)$ \\
\hline Punjabi & $72(26.1)$ & $7 I(26.4)$ & $143(26.2)$ \\
\hline Sindhi & $52(18.8)$ & $37(13.8)$ & $89(16.3)$ \\
\hline Balochi & $3(1.1)$ & $6(2.2)$ & $9(1.7)$ \\
\hline Afghan & $3(1.1)$ & $19(17.1)$ & $22(4.0)$ \\
\hline Others & $55(19.9)$ & $79(29.0)$ & $133(24.4)$ \\
\hline \multicolumn{4}{|l|}{ Education } \\
\hline None & $136(49.3)$ & $148(55.0)$ & $284(52.1)$ \\
\hline Religious only & $36(13.0)$ & $82(30.5)$ & $118(21.7)$ \\
\hline Some school & $103(37.3)$ & $39(14.5)$ & $142(26.1)$ \\
\hline \multicolumn{4}{|l|}{ Marital Status } \\
\hline Married & $26 I(95.6)$ & $22 I(82.5)$ & $482(88.4)$ \\
\hline Single & $7(2.6)$ & $8(3.0)$ & $15(2.8)$ \\
\hline Divorced/Widowed & $5(1.9)$ & $39(14.6)$ & $44(8.1)$ \\
\hline
\end{tabular}

tion of our participants was compared with that of the census data.

\section{Data Collection and Diagnosis}

A study clinic was organized by this project team at the Maternal and Child Health Clinic, Bilal Colony. This clinic was divided into three areas - Interview (Area I), Neurological Assessment (Area II) and Physical Examination, Anthropometry and Measurements (Area III). Logis- tics were designed to facilitate automatic transfer from Area I through III of each participant. Each participant would register at Area I. After explanation of the study procedure and written informed consent, all participants underwent a structured interview with physicians trained in using a standardized questionnaire. This questionnaire was based on the Stroke Symptom Questionnaire (SSQ) and the TIA Symptom Questionnaire, which was translated into Urdu by three independent translators and a 
Table 2: Life-time prevalence of stroke and transient ischemic attack (TIA) in population sub-groups

\begin{tabular}{|c|c|c|c|c|c|c|c|}
\hline & & \multicolumn{2}{|r|}{ Stroke $(n=104)$} & \multicolumn{2}{|r|}{ TIA $(n=53)$} & \multicolumn{2}{|r|}{ Stroke/TIA (n = I I9) } \\
\hline & & $\mathbf{n}$ & $\%(95 \% \mathrm{Cl})$ & $\mathbf{n}$ & $\%(95 \% \mathrm{Cl})$ & $\mathbf{n}$ & $\%(95 \% \mathrm{Cl})$ \\
\hline \multicolumn{8}{|c|}{ Gender } \\
\hline & Male & 32 & II.6 (7.8-15.4) & 16 & $5.8(3.0-8.6)$ & 40 & $14.5(10.3-18.7)$ \\
\hline & Female & 72 & $26.8(21.4-32.1)$ & 37 & |3.7(9.6-17.9) & 79 & $29.4(23.9-34.8)$ \\
\hline \multicolumn{8}{|c|}{ Age (years) } \\
\hline & $35-45$ & 50 & $17.4(13.2-22.3)$ & 27 & $9.4(6.3-13.4)$ & 55 & $19.2(14.8-24.2)$ \\
\hline & $46-55$ & 25 & $21.6(14.5-30.1)$ & 11 & $9.5(4.1-14.9)$ & 29 & $25.0(17.4-33.9)$ \\
\hline & $56-65$ & 15 & $19.5(11.3-30.1)$ & 8 & $10.4(3.4-17.4)$ & 19 & $24.7(15.6-35.8)$ \\
\hline & $66-75$ & 9 & $20.9(10.0-36.0)$ & 3 & $7.0(1.5-19.1)$ & 10 & $23.3(11.8-38.6)$ \\
\hline & More than 75 & 5 & $22.7(7.8-45.4)$ & 4 & $18.2(5.2-40.3)$ & 6 & $27.2(10.7-50.2)$ \\
\hline \multicolumn{8}{|c|}{ Ethnicity } \\
\hline & Pathan & 24 & $16.1(10.6-23.0)$ & 13 & $8.7(4.7-\mid 4.5)$ & 29 & $19.5(13.4-26.7)$ \\
\hline & Punjabi & 27 & $18.9(\mid 2.8-26.3)$ & 17 & $11.9(7.1-18.4)$ & 32 & $22.4(15.8-30.1)$ \\
\hline & Sindhi & 16 & $18.0(10.6-27.5)$ & 10 & II.2 (5.5-19.7) & 18 & $20.2(12.4-30.1)$ \\
\hline & Balochi & 4 & 44.4 (I3.7-78.8) & 2 & $22.2(2.8-60.0)$ & 4 & $44.4(13.7-78.8)$ \\
\hline & Afghan & 9 & $41.0(20.7-63.6)$ & 5 & $22.7(7.8-45.4)$ & 9 & $31.0(20.7-63.6)$ \\
\hline & Others & 24 & $18.0(11.9-25.6)$ & 6 & $4.5(1.7-9.6)$ & 27 & $20.3(13.8-28.1)$ \\
\hline Total & & 104 & I9.I (I5.9-22.6) & 53 & $9.7(7.4-12.5)$ & 119 & $21.8(18.4-25.5)$ \\
\hline
\end{tabular}

Note: TIA - transient ischemic attack, $\mathrm{Cl}$ - confidence interval

final version was selected after group review [14] The questionnaire was divided into the following sections: 1) socio-demographics, 2) stroke symptoms ever experienced, 3) TIA symptoms experienced in the last 12 months, 4) known risk factors. Pre-testing of the questionnaire was carried out on 35 individuals with a similar age and socioeconomic status distribution as the study population. A copy of the questionnaire can be found here (English: Additional file 1; Urdu: Additional file 2). All participants were shown photographs depicting amaurosis fugax, diplopia, triplopia (triple vision; perception of three images of a single object), hemianopia, hemiparesis and facial paresis as a part of their interview (see Additional file 3). Following the interview, any cases suspected to have had stroke or TIA were examined and confirmed by a vascular neurologist on site (Area II). Stroke and TIA were defined using published criteria[15,16] Anthropometric measurements and random blood glucose levels using Abbott MediSense Optium Glucose Monitor were recorded in all participants. All instruments used for anthropometric measurements were calibrated on a daily basis. The study protocol was approved by the Ethical Review Committee at Aga Khan University. Informed consent and verbal assent was given by all participants prior to the interview. Participants who met the eligibility criteria but were unable to travel to the study site due to financial or physical reasons were provided transport. Interviews were also conducted on holiday weekends to 

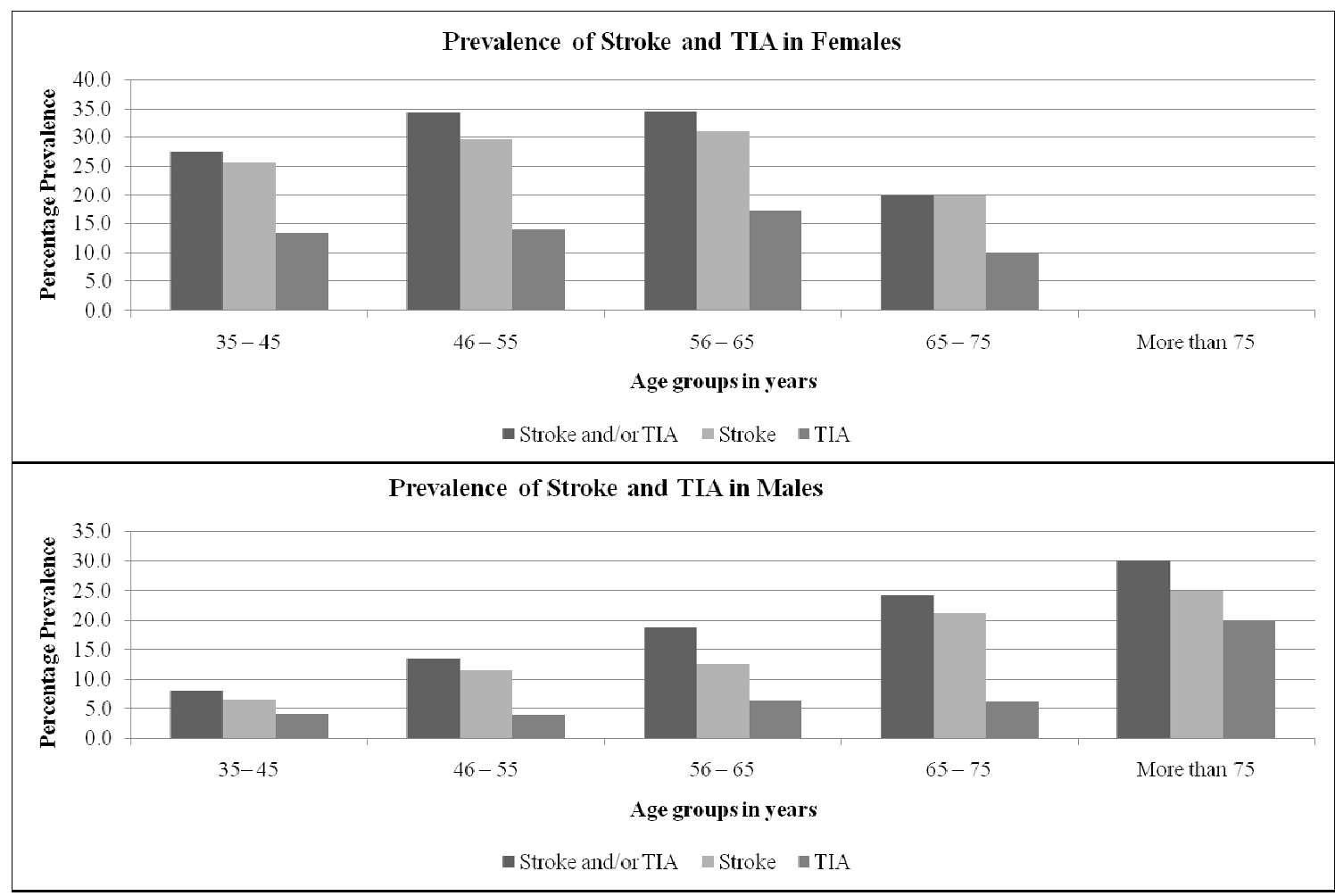

Figure 2 - Age-stratified prevalence of stroke and transient ischemic attack in males and females

\section{Figure 2}

Age-stratified prevalence of cerebrovascular disease in males and females: the life-time prevalence of CVD in females was similar in all age groups $(p=0.6 \mathrm{I})$ while that in males rose with old age $(p=0.025)$. $*$ TIA $=$ Transient Ischemic Attack.

ensure the participation of daily wage workers without any financial repercussions. No financial incentives were provided to any study participant. An overview of the study design is presented in figure 1 .

\section{Statistical Analysis}

All data was entered twice by two individuals separately and was cross-checked to ensure that no errors were made during the process. Prevalence estimates of stroke, and transient ischemic attack were reported with $95 \%$ confidence intervals (CI). Vascular risk factors between various groups were compared using univariate logistic regression to calculate odds ratios and 95\% CIs. Variables significant at $\mathrm{p}<0.1$ were included in the final multivariable logistic regression model. Data was analyzed using Stata version 10.0 (StataCorp. LP, TX, USA)

\section{Results}

A total of 545 individuals including $49.4 \%$ females took part in the study with a response rate of $90.8 \%$. As com- pared to the community census data of individuals older than 35 years, we had a slightly higher proportion of females in our sample (49.4\% in this sample v/s $43.9 \%$ in the census, $\mathrm{p}=0.012$ ). The mean age \pm standard deviation (SD) of responders was $48.7 \pm 12.8$ years while that found in the census data was $46.6 \pm 11.1$ years $(\mathrm{p}<0.001)$. Characteristics of the study population have been described in table 1.

Stroke was reported in 104 individuals $(19.1 \%$ with $69.2 \%$ female) while TIA was reported in 53 individuals (9.7\% with $69.8 \%$ female). Overall, stroke and/or TIA were found in 119 individuals $(21.8 \%$ with $66.4 \%$ females). The prevalence of stroke and TIA across gender, age groups and ethnicities has been shown in table 2. Agestratified prevalence of stroke and TIA in males and females is presented in figure 2 .

Female gender ( $p<0.001)$, family history of coronary artery disease or stroke $(\mathrm{p}=0.013)$, elevated random 
Table 3: Risk factor profile and non-adjusted Odds Ratios for stroke and/or transient ischemic attack.

\begin{tabular}{|c|c|c|c|c|}
\hline & No CVD & Stroke/TIA & Non-adjusted odds ratio & P-value \\
\hline & $n(\%)^{a}$ & $n(\%)^{a}$ & OR $(95 \% \mathrm{CI})$ & \\
\hline Age, years (SD) & $48.3(12.7)$ & $50.0(12.8)$ & $1.01(0.99-1.03)$ & 0.192 \\
\hline Female gender & $190(44.6)$ & $79(66.4)$ & $2.45(1.60-3.75)$ & $<0.001$ \\
\hline Family history of CAD or Stroke & $86(20.2)$ & $37(31.1)$ & $1.78(1.13-2.81)$ & 0.013 \\
\hline Past Myocardial Infarction & $24(5.6)$ & II (II.8) & $2.23(1.12-4.47)$ & 0.023 \\
\hline Systolic BP, mmHg (SD) & $128.6(21.0)$ & I $34.9(27.3)$ & $1.06(1.02-1.11)^{b}$ & 0.008 \\
\hline Diastolic BP, mmHg (SD) & $81.8(12.1)$ & $84.2(14.2)$ & $\mathrm{I} .08(0.997-\mathrm{I} .167)^{\mathrm{b}}$ & 0.061 \\
\hline Hypertensionc & $203(47.7)$ & $76(63.9)$ & $1.94(1.28-2.95)$ & 0.002 \\
\hline Random Blood Glucose, mg/dL (SD) & $141.6(69.6)$ & I64.I (86.9) & $1.02(1.005-1.030)^{2}$ & 0.004 \\
\hline Elevated RBS ${ }^{d}$ & $74(17.4)$ & $36(30.3)$ & $2.06(1.30-3.28)$ & 0.002 \\
\hline Smoking & $123(28.9)$ & $25(21.0)$ & $0.66(0.40-1.07)$ & 0.090 \\
\hline Pan, Gutka or Supari Use & $78(18.3)$ & $30(25.2)$ & $1.50(0.93-2.43)$ & 0.096 \\
\hline Weight, kg (SD) & $67.7(17.3)$ & $69.0(19.2)$ & $1.00(0.99-1.02)$ & 0.468 \\
\hline Body mass index, $\mathrm{kg} / \mathrm{m}^{2}(\mathrm{SD})$ & $26.6(8.0)$ & $27.5(6.1)$ & $1.01(0.99-1.04)$ & 0.269 \\
\hline Obesity f & $229(53.8)$ & $81(68.1)$ & $1.83(1.19-2.82)$ & 0.006 \\
\hline Waist Circumference, cm (SD) & $93.2(13.6)$ & $94.7(16.0)$ & $1.01(0.99-1.02)$ & 0.301 \\
\hline Waist-Hip Ratio (SD) & $0.94(0.09)$ & $0.93(0.08)$ & $0.46(0.05-4.72)$ & 0.516 \\
\hline Elevated WHRg & $375(88.0)$ & $109(91.6)$ & $1.48(0.73-3.02)$ & 0.278 \\
\hline Menopause $^{h}$ & $98(57.7)$ & $47(62.7)$ & $1.23(0.71-2.15)$ & 0.462 \\
\hline
\end{tabular}

Note: WHR - Waist-hip Ratio, BMI - Body mass index, RBS - Random Blood Sugar, CAD - Coronary Artery Disease, BP - Blood Pressure, SD -

Standard Deviation, TIA - Transient Ischemic Attack, Cl - Confidence Interval.

aGiven as $\mathrm{n}(\%)$ except where stated specifically.

bCalculated for each 5 unit increase.

cDefined as systolic BP greater than or equal to $140 \mathrm{mmHg}$ or diastolic BP greater than or equal to $90 \mathrm{mmHg}$ on two readings at least 10 minutes

apart and/or self-reported history of persistent hypertension.

Raised Random Blood Sugar level greater than or equal to $180 \mathrm{mg} / \mathrm{dL}$ on one reading.

ePan, gutka and supari are locally available forms of chewable tobacco.

fDefined as body mass index more than or equal to $25 \mathrm{~kg} / \mathrm{m}^{2}$.

gDefined as waist-hip ratio greater than 0.88 in males and 0.81 in females.

hMenopause was considered in the female subset of our sample only.

blood sugar $(\mathrm{p}=0.004)$, hypertension $(\mathrm{p}=0.002)$, body mass index $\geq 25 \mathrm{~kg} / \mathrm{m}^{2}(\mathrm{p}=0.006)$ and past history of myocardial infarction $(\mathrm{p}=0.023)$ were significantly associated with risk of stroke and/or TIA on univariate analysis. In the multivariable model, old age, female gender, family history of coronary artery disease or stroke, elevated random blood sugar and use of chewable tobacco products were significantly associated with risk of stroke and/or TIA. Univariate and multivariable analysis of risk factors is presented in table 3 and table 4 respectively. 
Table 4: Results of multivariable analysis of significant risk factors for stroke and/or transient ischemic attack.

\begin{tabular}{|c|c|c|c|c|}
\hline & No CVD & Stroke/TIA & Adjusted odds ratio & P-value \\
\hline & $n(\%)^{a}$ & n (\%) ${ }^{a}$ & OR $(95 \% \mathrm{Cl})$ & \\
\hline Age, years (SD) & $48.3(12.7)$ & $50.0(12.8)$ & $1.022(1.003-1.041)$ & 0.021 \\
\hline Female gender & $190(44.6)$ & $79(66.4)$ & $2.62(1.56-4.40)$ & $<0.001$ \\
\hline Family history of CAD or Stroke & $86(20.2)$ & $37(31.1)$ & $1.65(1.02-2.69)$ & 0.042 \\
\hline Past Myocardial Infarction & $24(5.6)$ & II (II.8) & $1.62(0.77-3.39)$ & 0.205 \\
\hline Hypertension ${ }^{b}$ & $203(47.7)$ & $76(63.9)$ & $1.25(0.78-2.00)$ & 0.504 \\
\hline Elevated RBSc & $74(17.4)$ & $36(30.3)$ & $1.76(1.07-2.90)$ & 0.026 \\
\hline Smoking & $123(28.9)$ & $25(21.0)$ & $1.03(0.58-1.83)$ & 0.921 \\
\hline Pan, Gutka or Supari Use & $78(18.3)$ & $30(25.2)$ & $2.06(1.22-3.49)$ & 0.007 \\
\hline Obesityd & $229(53.8)$ & $81(68.1)$ & $\mathrm{I} .49(0.92-2.4 \mathrm{I})$ & 0.104 \\
\hline
\end{tabular}

Note: RBS - Random Blood Sugar, CAD - Coronary Artery Disease, BP - Blood Pressure, SD - Standard Deviation, TIA - Transient Ischemic Attack, $\mathrm{Cl}$ - Confidence Interval. Variables biologically plausible or significant at $\mathrm{p}<0.100$ on univariate analysis were included in this model. aGiven as $\mathrm{n}(\%)$ except where stated specifically.

bDefined as systolic BP greater than or equal to $140 \mathrm{mmHg}$ or diastolic BP greater than or equal to $90 \mathrm{mmHg}$ on two readings at least 10 minutes apart and/or self-reported history of persistent hypertension.

cRaised Random Blood Sugar level greater than or equal to $180 \mathrm{mg} / \mathrm{dL}$ on one reading.

dDefined as body mass index more than or equal to $25 \mathrm{~kg} / \mathrm{m}^{2}$.

Of the patients who reported stroke or TIA, 7\% reported residual disability (Modified Rankin Score2-4) whereas 93\% were symptom-free (Modified Rankin Score 0).

\section{Discussion}

This study is the first urban population based estimate of life-time prevalence of cerebrovascular disease in Pakistan that shows an alarmingly high burden of disease. In comparison to existing worldwide literature on stroke prevalence, this study shows a prevalence of stroke which is almost twice the highest reported prevalence in the world to date (table 5) $[17,18]$ A prior study reported a stroke prevalence of $4.8 \%$ in a single ethnic group in Pakistan[4] However, the definition of stroke used in this study was limited to the presence of sustained hemiparesis for more than 24 hours. Given the wide variety of presentations of stroke, it is likely to be an underestimate of the true burden. In comparison, we report about 1 in 5 people in our sample have suffered from stroke or TIA. In addition, our data also suggests that patients who have suffered from stroke in Pakistan have an average age of about 50 years which is almost a decade younger than their western counterparts. A previous study from Pakistan has reported about $25 \%$ prevalence of coronary artery disease in a middle-aged sample[19] Hence, our results reiterate the exceptionally high burden of atherosclerotic diseases in Pakistan. In addition, family history of coronary artery disease increased the risk of stroke and/or TIA by at least $32 \%$ in our sample. These findings highlight the shared genetic and environmental etiologies that may have a role in atherosclerotic vascular disease in the South Asian population.

We further suggest that females are at a higher risk of stroke and/or transient ischemic attack in our population and this finding is independent of all other risk factors. Females were well-represented in this sample as the study site was visited by women frequently and they did not require male chaperones to participate in the study. Hence, the design of this study ensured appropriate participation of females, a usually under-represented group.

The age standardized prevalence of stroke and TIA followed a predictable rise with old age in men while it was evenly distributed across all age groups in females (figure 2 ). These findings suggest gender specific susceptibility to etiologies in addition to atherosclerosis. Further studies looking at specific vascular risk factors unique to females are needed. These studies may be focused on eclampsia, cerebral venous sinus thrombosis, gestational diabetes and stroke - these are beyond the scope of the current study[20] Since $70 \%$ of all births are at home and attended by traditional birth attendants, such studies require a community based design[21] 
Table 5: Comparison of worldwide prevalence of stroke over the last 20 years

\begin{tabular}{|c|c|c|c|c|c|}
\hline Author & $\begin{array}{l}\text { Method of Diagnosis } \\
\text { of Stroke }\end{array}$ & Study Method & $\begin{array}{c}\text { Sample } \\
\text { Population }\end{array}$ & Year & Important Findings \\
\hline Bharucha et al[24] & $\begin{array}{c}\text { Clinical diagnosis by a } \\
\text { neurologist }\end{array}$ & $\begin{array}{l}\text { Population-based } \\
\text { door-to-door survey }\end{array}$ & $\begin{array}{l}\text { India, Bombay } \\
(\mathrm{n}=14010)\end{array}$ & 1988 & $\begin{array}{c}\text { Crude prevalence was } 842 \text { per } 100 \\
000 \text { population; age-specific rates } \\
\text { were higher in men }\end{array}$ \\
\hline $\begin{array}{l}\text { Mittelmark et } \\
\text { al[25] }\end{array}$ & $\begin{array}{l}\text { Self-reported history } \\
\text { plus medical record } \\
\text { confirmation }\end{array}$ & $\begin{array}{l}\text { Population based } \\
\text { longitudinal study }\end{array}$ & $\begin{array}{l}\text { Four regions, USA } \\
\qquad(n=5,201)\end{array}$ & $1989-90$ & $\begin{array}{l}\text { Crude prevalence rate was } 246 \text { per } \\
\qquad 100,000 a\end{array}$ \\
\hline Bots et al[26] & $\begin{array}{l}\text { Self-reported history } \\
\text { plus medical record } \\
\text { confirmation }\end{array}$ & $\begin{array}{l}\text { Population-based, } \\
\text { cohort }\end{array}$ & $\begin{array}{l}\text { Rotterdam, } \\
\text { Netherlands } \\
(n=7983)\end{array}$ & $1990-93$ & $\begin{array}{l}\text { A total of } 352 \text { individuals out of } \\
7983 \text { were reported to have a } \\
\text { stroke, while an additional } 285 \\
\text { were reported with clinical data. } \\
\text { This represents a crude prevalence } \\
\text { rate of } 7979 \text { per } 100,000 \mathrm{a}\end{array}$ \\
\hline Geddes et al[27] & $\begin{array}{l}\text { Self-reported stroke } \\
\text { questionnaire through } \\
\text { postal service }\end{array}$ & $\begin{array}{l}\text { Population based, } \\
\text { point prevalence } \\
\text { study }\end{array}$ & $\begin{array}{l}\text { Yorkshire, UK } \\
(\mathrm{n}=18,827)\end{array}$ & 1991 & $\begin{array}{c}\text { Crude prevalence rate was } 4680 \\
\text { per } 100,000, \text { with males having a } \\
\text { higher prevalence }\end{array}$ \\
\hline Bonita et al[28] & $\begin{array}{l}\text { Clinical diagnosis using } \\
\text { WHO definition }\end{array}$ & $\begin{array}{l}\text { Retrospective analysis } \\
\text { of hospital, clinical } \\
\text { and autopsy record }\end{array}$ & $\begin{array}{c}\text { Auckland, New } \\
\text { Zealand }(n=854000 \\
\text { and } 945000)^{b}\end{array}$ & $1991-92$ & $\begin{array}{l}\text { Age-adjusted rate was } 833 \text { per } 100 \text {, } \\
000\end{array}$ \\
\hline Prencipe et al[29] & $\begin{array}{l}\text { Self-reported history } \\
\text { followed by neurological } \\
\text { examination }\end{array}$ & $\begin{array}{l}\text { Community-based, } \\
\text { door-to-door survey }\end{array}$ & $\begin{array}{l}\text { L'Aquila, Italy } \\
\qquad(\mathrm{n}=1032)\end{array}$ & 1992 & $\begin{array}{c}\text { Crude prevalence rate was } 7300 \\
\text { per } 100,000 \text {. Prevalence of stroke } \\
\text { was higher in men and increased } \\
\text { with age in both sexes }\end{array}$ \\
\hline O'Mahony et al[30] & $\begin{array}{l}\text { Screening questionnaire } \\
\text { followed by clinical } \\
\text { confirmation using } \\
\text { WHO criteria }\end{array}$ & $\begin{array}{l}\text { Population based, } \\
\text { point prevalence } \\
\text { study }\end{array}$ & $\begin{array}{l}\text { Newcastle, UK } \\
(n=2000)\end{array}$ & 1993 & $\begin{array}{c}\text { Crude prevalence rate was } 4740 \\
\text { per } 100,000, \text { while age adjusted } \\
\text { rates were } 1750 \text { per } 100,000 . \\
\text { Prevalence increased } \\
\text { proportionately in older age groups }\end{array}$ \\
\hline Huang et al[3I] & unclear & $\begin{array}{l}\text { Population-based, } \\
\text { Cross sectional?? }\end{array}$ & $\begin{array}{l}\text { Taiwan, China } \\
(n=11,925)\end{array}$ & 1994 & $\begin{array}{l}\text { Crude prevalence rate was } 595 \text { per } \\
\qquad 100,000\end{array}$ \\
\hline Nicoletti et al[32] & $\begin{array}{l}\text { WHO Stroke screening } \\
\text { instrument }\end{array}$ & $\begin{array}{l}\text { Population based } \\
\text { door-to-door survey }\end{array}$ & $\begin{array}{l}\text { Cordillera, Bolivia } \\
\qquad(n=9955)\end{array}$ & 1994 & $\begin{array}{l}\text { Crude prevalence rate was } 663 \text { per } \\
100,000 \text { for those }>/=35 \text { years. } \\
\text { Prevalence in men was } 2 \times \text { greater } \\
\text { than women }\end{array}$ \\
\hline Banergee et al[33] & $\begin{array}{l}\text { Clinical diagnosis by a } \\
\text { neurologist or CT } \\
\text { imaging }\end{array}$ & $\begin{array}{l}\text { Population-based } \\
\text { cluster survey }\end{array}$ & $\begin{array}{l}\text { India, Calcutta } \\
(n=50291)\end{array}$ & 1998-1999 & $\begin{array}{c}\text { Crude prevalence was } 147 \text { and age- } \\
\text { adjusted rate was } 334 \text { per } 100000 \\
\text { population; females had higher } \\
\text { prevalence in all age groups }\end{array}$ \\
\hline Anand et al[34] & $\begin{array}{l}\text { Self-reported history or } \\
\text { clinical diagnosis by } \\
\text { physician }\end{array}$ & $\begin{array}{l}\text { Population-based } \\
\text { cross-sectional }\end{array}$ & Canada $(\mathrm{n}=985)$ & 2000 & $\begin{array}{l}\text { Crude prevalence rates were } \\
\text { similar among ethnic groups: South } \\
\text { Asians: } 300 \text {, European whites: } 1800 \text {, } \\
\text { and Chinese: } 600 \text { per } 100000 \\
\text { population }\end{array}$ \\
\hline AASAP[35] & Unclear & $\begin{array}{l}\text { Based on national } \\
\text { health records of } \\
\text { individual country }\end{array}$ & $\begin{array}{l}\text { Nine Asian countries } \\
\text { (Pakistan was not } \\
\text { part of this study) }\end{array}$ & 2000 & $\begin{array}{c}\text { Crude prevalence in India ranges } \\
\text { from } 90-222 \text { per } 100000 ; \text { Thailand } \\
\text { and Taiwan had higher reported } \\
\text { prevalence rates (690 and 1430) } \\
\text { per } 100000\end{array}$ \\
\hline Jafar et al[4] & Self-reported history & $\begin{array}{l}\text { Community survey } \\
\text { and target sampling }\end{array}$ & Pakistan $(n=500)$ & 2001 & $\begin{array}{l}\text { Crude prevalence was } 4800 \text { per } \\
\qquad 100000\end{array}$ \\
\hline
\end{tabular}


Table 5: Comparison of worldwide prevalence of stroke over the last 20 years (Continued)

\begin{tabular}{|c|c|c|c|c|c|}
\hline $\begin{array}{c}\text { Venketa- } \\
\text { subramanium et } \\
\mathrm{al}[36]\end{array}$ & $\begin{array}{l}\text { Clinical diagnosis using } \\
\text { WHO definition }\end{array}$ & $\begin{array}{l}\text { Population-based, } \\
\text { cross-sectional }\end{array}$ & $\begin{array}{c}\text { Singapore } \\
(n=15606)\end{array}$ & $200 I-2003$ & $\begin{array}{c}\text { Crude as well as age-standardized } \\
\text { rates were similar among ethnic } \\
\text { groups (SA: } 362 \text {, Malays: } 332, \\
\text { Chinese: } 376) \text { per } 100000 \\
\text { population }\end{array}$ \\
\hline $\begin{array}{l}\text { Department of } \\
\text { Health Survey for } \\
\text { England[37] }\end{array}$ & $\begin{array}{l}\text { Clinical diagnosis using } \\
\text { WHO definition }\end{array}$ & $\begin{array}{c}\text { Population-based } \\
\text { door-to-door health } \\
\text { survey }\end{array}$ & $\begin{array}{c}\text { Stratified } \\
\text { proportionate } \\
\text { sample from general } \\
\text { population }\end{array}$ & 2005 & $\begin{array}{l}\text { Crude prevalence in South Asians } \\
\text { (Indian: II00, Pakistani: } 1800, \\
\text { Bangladeshi: 1800) were lower than } \\
\text { European Whites (2400) per } 100 \\
000 \text { population }\end{array}$ \\
\hline $\begin{array}{c}\text { This Study - Kamal } \\
\text { et al }\end{array}$ & $\begin{array}{l}\text { Self-reported history } \\
\text { based on SSQ followed } \\
\text { by neurological } \\
\text { examination }\end{array}$ & $\begin{array}{l}\text { Community-based } \\
\text { following census }\end{array}$ & $\begin{array}{l}\text { Karachi, Pakistan } \\
\quad(n=545)\end{array}$ & $2008-2009$ & $\begin{array}{c}\text { Crude prevalence was determined } \\
\text { to be } 19000 \text { per } 100,000 \text {. Women } \\
\text { found to have a higher prevalence } \\
\text { of stroke and at an earlier age than } \\
\text { men. }\end{array}$ \\
\hline
\end{tabular}

WHO: World Health Organization

SA: South Asian

SSQ: Stroke Symptom Questionnaire

a Calculated using information from the publication cited

btwo separate studies done ten years apart

Uncontrolled diabetes and use of chewable tobacco were two modifiable risk factors independently associated with stroke and/or TIA. About 1 in 3 stroke patients were found to have uncontrolled diabetes which conferred at least a $7 \%$ increased risk of stroke and/or TIA after adjustment for all other risk factors. Overall, the prevalence of raised random blood sugar was $20 \%$ which is lower than but comparable to the prevalence of diabetes reported earlier[4] Similarly, 1 in 4 patients used chewable tobacco in the form of pan, gutka or supari (locally available forms with areca and betel nut) which increased their risk of stroke and/or TIA by at least $22 \%$ after adjustment. The overall prevalence of chewable tobacco was similar to that reported by an earlier survey conducted in the same community[22]

Hypertension was found in about $50 \%$ of all participants while increase in each $5 \mathrm{mmHg}$ of systolic blood pressure significantly increased the risk of stroke and/or TIA by at least $2 \%$ on univariate analysis. Hypertension, as defined by elevated systolic or diastolic blood pressure or selfreported past medical history of hypertension, was significantly associated with stroke and/or TIA on univariate analysis but did not reach statistical significance in the final adjusted model. About $57 \%$ of the participants were obese with body mass index $\geq 25 \mathrm{~kg} / \mathrm{m}^{2}$ and obesity increased the risk of stroke and/or TIA by at least $19 \%$ on univariate analysis.

We confirm the association of known modifiable risk factors with cerebrovascular disease in Pakistan. Similar reports of high burden of cardiovascular risk factors have been published earlier [4-6] Our data also shows that only $19 \%$ of stroke patients in this study were aware of their condition while about $58 \%$ of all participants with ele- vated blood pressures were aware that they had hypertension. These findings highlight the need for community education about modifiable vascular risk factors. They also call attention to the role that general practitioners can play in our setup through promotion of lifestyle modifications and through aggressive therapeutic control of diabetes and hypertension in order to lower the risk of stroke and TIA in the community.

The strengths of this study include standardization using a pre-tested questionnaire, on site verification of diagnosis by a vascular neurologist, a random sample from a multiethnic population and appropriate arrangements for representation of women and daily wage workers. The use of a combination of questions to assess stroke and TIA prevalence has been shown to improve sensitivity at the risk of false positives[23] We also used photographs of the experience of visual symptoms of stroke and TIA to assist in clear diagnosis. For example, participants could clearly identify historically whether they had "non-specific clouding of vision" vs. "hemianopia" by looking at a photograph depicting hemianopia. While this approach may have increased the specificity of the visual section of our questionnaire, we have not measured this effect.

Our sample size may have limited power to study independent associations with all possible risk factors. We were unable to confirm an association with smoking perhaps because the population prefers indigenous means of tobacco intake over cigarette smoking. As compared to the census data, mean age of our sample around two years greater and we had a slightly higher representation of females. However, the prevalence of vascular risk factors in our sample is similar to that reported earlier in litera- 
ture. Hence, we believe that the findings of this study are reliable and a call for action.

Since the site of the study was located in an urban slum of Pakistan with a predominantly low socioeconomic status, the results of this study may not be completely applicable in the rural areas of the country where the prevalence may be lower as "demographic transition" may not have occurred. However, they may be applied in similar socioeconomic strata in Pakistan.

\section{Conclusion}

We report an alarmingly high burden of stroke and TIA in the urban Pakistani population. Our findings mimic the reported prevalence of cardiovascular disorders and their risk factors in Pakistan[4,19] The association of female gender and local chewable tobacco use with stroke begs further investigation. Community awareness about stroke and its modifiable risk factors was limited. Individual and public health interventions in Pakistan to increase awareness of stroke, its prevention and therapy are warranted.

\section{Source of funding}

This study was funded by the University Research Council at Aga Khan University Grant Number: URC Project ID 07GS021MED. This is part of the "small grants program".

\section{Competing interests}

The authors declare that they have no competing interests.

\section{Authors' contributions}

AK conceived the study, supervised data collection and wrote the manuscript. AI performed study coordination, field management and was involved in all stages of the project including writing the grant. $\mathrm{MM}, \mathrm{MK}, \mathrm{AR}, \mathrm{AA}, \mathrm{AA}$, ZA, NI, SS, FM performed field work, manuscript writing and data entry. MM and AI performed statistical analysis. DS generated a randomization list and provided statistical overview. All authors have read and reviewed the final manuscript.

\section{Additional material}

\section{Additional file 1}

Supplement 1. The Burden of Stroke and Transient Ischemic Attacks in Pakistan: a Community-based Prevalence Study (English).

Click here for file

[http://www.biomedcentral.com/content/supplementary/14712377-9-58-S1.PDF]

\section{Additional file 2}

Supplement 2. The Burden of Stroke and Transient Ischemic Attacks in Pakistan: a Community-based Prevalence Study (Urdu).

Click here for file

[http://www.biomedcentral.com/content/supplementary/14712377-9-58-S2.PDF]

\section{Additional file 3}

Supplement 3. This PDF contains the visual aids used in the study. Click here for file

[http://www.biomedcentral.com/content/supplementary/14712377-9-58-S3.PDF]

\section{Acknowledgements}

We wish to acknowledge Dr. Zulfiqar Bhutta (Professor and Chair, Department of Pediatrics and Child Health, Aga Khan University Hospital) for his facilitation of this study and provision of census data, Dr. Hafeez ur Rahman Bhutto for site management, Mr. Imran Ahmed for responding to data queries specific to Bilal Colony, Ms. Shahida Parveen for assisting with multilingual translations, Dr. Mughis Sheerani for facilitation of resident participation, and finally the community health workers and the community of Bilal Colony.

\section{References}

I. Feigin VL, Lawes CM, Bennett DA, Barker-Collo SL, Parag V: Worldwide stroke incidence and early case fatality reported in $\mathbf{5 6}$ population-based studies: a systematic review. Lancet Neurol 2009, 8(4):355-369.

2. Omran AR: The epidemiologic transition. A theory of the epidemiology of population change. Milbank Mem Fund $Q$ 1971, 49(4):509-538.

3. Truelsen T, Heuschmann P, Bonita R, Arjundas G, Dalal P, Damasceno A, Nagaraja D, Ogunniyi A, Oveisgharan S, Radhakrishnan K, et al.: Standard method for developing stroke registers in lowincome and middle-income countries: experiences from a feasibility study of a stepwise approach to stroke surveillance (STEPS Stroke). Lancet Neurol 2007, 6(2): 134-139.

4. Jafar TH: Blood pressure, diabetes, and increased dietary salt associated with stroke--results from a community-based study in Pakistan. J Hum Hypertens 2006, 20(I):83-85.

5. Jafar TH, Chaturvedi N, Pappas G: Prevalence of overweight and obesity and their association with hypertension and diabetes mellitus in an Indo-Asian population. CMAJ 2006, 175(9): 107|- 1077

6. Alam AY, lqbal A, Mohamud KB, Laporte RE, Ahmed A, Nishtar S: Investigating socio-economic-demographic determinants of tobacco use in Rawalpindi, Pakistan. BMC Public Health 2008, 8:50.

7. Johnston SC, Gress DR, Browner WS, Sidney S: Short-term prognosis after emergency department diagnosis of TIA. JAMA 2000, 284(22):290I-2906.

8. Kamal A, Khimani F, Raza R, Zafar S, Bandeali S, Jan S: Characteristics of TIA and its management in a tertiary care hospital in Pakistan. BMC Res Notes 2008, I:73.

9. Rothwell PM, Giles MF, Chandratheva A, Marquardt L, Geraghty O Redgrave JN, Lovelock CE, Binney LE, Bull LM, Cuthbertson FC, et al: Effect of urgent treatment of transient ischaemic attack and minor stroke on early recurrent stroke (EXPRESS study): a prospective population-based sequential comparison. Lancet 2007, 370(9596): | 432-| 442

10. Kennedy J, Hill MD, Ryckborst KJ, Eliasziw M, Demchuk AM, Buchan AM: Fast assessment of stroke and transient ischaemic attack to prevent early recurrence (FASTER): a randomised controlled pilot trial. Lancet Neurol 2007, 6(II):961-969.

II. Easton JD, Saver JL, Albers GW, Alberts MJ, Chaturvedi S, Feldmann E, Hatsukami TS, Higashida RT, Johnston SC, Kidwell CS, et al.: Definition and Evaluation of Transient Ischemic Attack. A Scientific Statement for Healthcare Professionals From the American Heart Association/American Stroke Association Stroke Council; Council on Cardiovascular Surgery and Anesthesia; Council on Cardiovascular Radiology and Intervention; Council on Cardiovascular Nursing; and the Interdisciplinary Council on Peripheral Vascular Disease. Stroke 2009, 40(6):2276-2293.

12. Sharieff W, Bhutta Z, Schauer C, Tomlinson G, Zlotkin S: Micronutrients (including zinc) reduce diarrhea in children: the Paki- 
stan Sprinkles Diarrhoea Study. Archives of disease in childhood 2006, 91 (7):573-579.

13. Gross National Income per Capita Atlas method and PPP [http://extsearch.worldbank.org/servlet/SiteSearchServ let?q=gross $\% 20 \% 20$ national\%20income $\% 20$ per $\% 20$ capita $\% 20$ ]

14. Berger K, Hense HW, Rothdach A, Weltermann B, Keil U: A single question about prior stroke versus a stroke questionnaire to assess stroke prevalence in populations. Neuroepidemiology 2000, I 9(5):245-257.

15. Brown MM, Rudd A, McGovern R: Transient ischemic attack-proposed new definition. N Engl J Med 2003, 348(16): 1607-1609. author reply 1607-1609

16. The WHO STEPwise approach to stroke surveillance. In WHO STEPS Stroke Manual World Health Organization; 2006.

17. Gunarathne A, Patel JV, Gammon B, Gill PS, Hughes EA, Lip GY: Ischemic stroke in South Asians: a review of the epidemiology, pathophysiology, and ethnicity-related clinical features. Stroke; a journal of cerebral circulation 2009, 40(6):e4I5-423.

18. Feigin VL, Lawes CM, Bennett DA, Anderson CS: Stroke epidemiology: a review of population-based studies of incidence, prevalence, and case-fatality in the late 20 th century. Lancet neurology 2003, 2(1):43-53.

19. Jafar TH, Jafary FH, Jessani S, Chaturvedi N: Heart disease epidemic in Pakistan: women and men at equal risk. American heart journal 2005, I 50(2):22I-226.

20. Treadwell SD, Thanvi B, Robinson TG: Stroke in pregnancy and the puerperium. Postgrad Med J 2008, 84(99I):238-245

21. Bhutta ZA, Ali N, Hyder AA, Wajid A: Perinatal and newborn care in Pakistan: seeing the unseen. In Maternal and child health in Pakistan: challenges and opportunities Edited by: Bhutta ZA. Karachi: Oxford University Press; 2004.

22. Mazahir S, Malik R, Maqsood M, Merchant KA, Malik F, Majeed A, Fatmi Z, Khawaja MR, Ghaffar S: Socio-demographic correlates of betel, areca and smokeless tobacco use as a high risk behavior for head and neck cancers in a squatter settlement of Karachi, Pakistan. Subst Abuse Treat Prev Policy 2006, I: 10.

23. Jungehulsing G], Muller-Nordhorn J, Nolte $\mathrm{CH}$, Roll S, Rossnagel K, Reich A, Wagner A, Einhaupl KM, Willich SN, Villringer A: Prevalence of stroke and stroke symptoms: a population-based survey of 28,090 participants. Neuroepidemiology 2008, 30(I):5I-57

24. Bharucha NE, Bharucha EP, Bharucha AE, Bhise AV, Schoenberg BS: Case-control study of completed ischemic stroke in the Parsis of Bombay: a population-based study. Neurology 1988 38(3):490-492.

25. Mittelmark MB, Psaty BM, Rautaharju PM, Fried LP, Borhani NO, Tracy RP, Gardin JM, O'Leary DH: Prevalence of cardiovascular diseases among older adults. The Cardiovascular Health Study. American journal of epidemiology 1993, I37(3):3| I-3|7.

26. Bots ML, Looman SJ, Koudstaal PJ, Hofman A, Hoes AW, Grobbee DE: Prevalence of stroke in the general population. The Rotterdam Study. Stroke; a journal of cerebral circulation 1996, 27(9):|499-|50|.

27. Geddes JM, Fear J, Tennant A, Pickering A, Hillman M, Chamberlain MA: Prevalence of self reported stroke in a population in northern England. Journal of epidemiology and community health 1996, 50(2): 140-143.

28. Bonita R, Solomon N, Broad JB: Prevalence of stroke and strokerelated disability. Estimates from the Auckland stroke studies. Stroke; a journal of cerebral circulation 1997, 28(10): 1898-1902.

29. Prencipe M, Ferretti C, Casini AR, Santini M, Giubilei F, Culasso F: Stroke, disability, and dementia: results of a population survey. Stroke; a journal of cerebral circulation 1997, 28(3):53 I-536.

30. O'Mahony PG, Thomson RG, Dobson R, Rodgers H, James OF: The prevalence of stroke and associated disability. Journal of public health medicine 1999, 2I(2):166-171.

31. Huang ZS, Chiang TL, Lee TK: Stroke prevalence in Taiwan. Findings from the 1994 National Health Interview Survey. Stroke; a journal of cerebral circulation 1997, 28(8): 1579-1584.

32. Nicoletti A, Reggio A, Bartoloni A, Failla G, Bartalesi F, Roselli M, Gamboa H, Salazar E, Paradisi F, Tempera G, et al.: A neuroepidemiological survey in rural Bolivia: background and methods. Neuroepidemiology 1998, I7(5):273-280.

33. Banerjee TK, Mukherjee CS, Sarkhel A: Stroke in the urban population of Calcutta--an epidemiological study. Neuroepidemiology 200I, 20(3):20I-207.
34. Anand SS, Yusuf S, Vuksan V, Devanesen S, Teo KK, Montague PA, Kelemen L, Yi C, Lonn E, Gerstein H, et al.: Differences in risk factors, atherosclerosis, and cardiovascular disease between ethnic groups in Canada: the Study of Health Assessment and Risk in Ethnic groups (SHARE). Lancet 2000, 356(9226):279-284.

35. Stroke epidemiological data of nine Asian countries. Asian Acute Stroke Advisory Panel (AASAP). Journal of the Medical Association of Thailand = Chotmaihet thangphaet 2000, 83(I): I-7.

36. Venketasubramanian N, Tan LC, Sahadevan S, Chin IJ, Krishnamoorthy ES, Hong CY, Saw SM: Prevalence of stroke among Chinese, Malay, and Indian Singaporeans: a community-based triracial cross-sectional survey. Stroke 2005, 36(3):55I-556.

37. Department of Health (2005) Health Survey for England: The Health of Minority Ethnic Groups, The Stationery Office. 2004.

\section{Pre-publication history}

The pre-publication history for this paper can be accessed here:

http://www.biomedcentral.com/1471-2377/9/58/prepub
Publish with Bio Med Central and every scientist can read your work free of charge

"BioMed Central will be the most significant development for disseminating the results of biomedical research in our lifetime. "

Sir Paul Nurse, Cancer Research UK

Your research papers will be:

- available free of charge to the entire biomedical community

- peer reviewed and published immediately upon acceptance

- cited in PubMed and archived on PubMed Central

- yours - you keep the copyright
BioMedcentral 